\title{
The Behavior of Indonesian Stock Market: Structural Breaks and Nonlinearity
}

\author{
Rahmat Heru Setianto \\ Department of Management Faculty of Economics and Business, Universitas Airlangga, Indonesia \\ Turkhan AliAbdul Manap \\ Department of Economics, Kulliyyah of Economics and Management Sciences, International Islamic University, \\ Malaysia
}

\begin{abstract}
This study empirically examines the behaviour of Indonesian stock market under the efficient market hypothesis framework by emphasizing on the random walk behaviour and nonlinearity over the period of April 1983 - December 2010. In the first step, the standard linear unit root test, namely the augmented Dickey-Fuller (ADF) test, Phillip-Perron (PP) test and Kwiatkowski-Phillips-Schmidt-Shin (KPSS) test identify the random walk behaviour in the indices. In order to take account the possible breaks in the index series Zivot and Adrews (1992) one break and Lumsdaine and Papell (1997) two breaks unit root test are employed to observe whether the presence of breaks in the data series will prevent the stocks from randomly pricing or vice versa. In the third step, we employ Harvey et al. (2008) test to examine the presence of nonlinear behaviour in Indonesian stock indices. The evidence of nonlinear behaviour in the indices, motivate us to use nonlinear unit root test procedure recently developed by Kapetanios et al. (2003) and Kruse (2010). In general, the results from standard linear unit root test, Zivot and Adrews (ZA) test and Lumsdaine and Papell (LP) test provide evidence that Jakarta Composite Index characterized by a unit root. In addition, structural breaks identified by ZA and LP test are corresponded to the events of financial market liberalization and financial crisis. The nonlinear unit root test procedure fail to rejects the null hypothesis of unit root for all indices, suggesting that Jakarta Composite Index characterized by random walk process supporting the theory of efficient market hypothesis.
\end{abstract}

\begin{abstract}
Abstrak: Penelitian ini secara empiris mengamati perilaku pasar saham Indonesia dalam kerangka hipotesis pasar yang efisien dengan menekankan pada perilaku pergerakan harga acak (random walk) dan nonlinier selama periode April 1983 - Desember 2010. Pada langkah pertama digunakan uji unit root yang standar dan linier, yaitu uji augmented Dickey-Fuller (ADF), Phillip-Perron (PP) dan Kwiatkowski-Philllips-SchmidtShin (KPSS), yang mengidentifikasi perilaku random walk pada indeks. Untuk memperhitungkan kemungkinan adanya patahan (breaks) dalam indeks, digunakan uji Zivot dan Adrews (1992) satu breaks dan Lumsdaine dan Papell (1997) dua breaks unit root, untuk mengamati apakah kehadiran patahan dalam seri data akan mempengaruhi perilaku harga saham dari perilaku random atau sebaliknya. Pada langkah ketiga, kami menggunakan model Harvey et al. (2008) untuk memeriksa adanya perilaku nonlinier dalam indeks saham Indonesia. Adanya temuan perilaku nonlinier dalam indeks, memotivasi peneliti untuk menggunakan
\end{abstract}

Corresponding authors. E-mail: rahmat.heru@feb.unair.ac.id, and turkhan@iium.edu.my

ISSN: $1141-1128$

http://www.gamaijb.mmugm.ac.id/ 
prosedur tes nonlinear unit root yang dikembangkan oleh Kapetanios et al. (2003) dan Kruse (2010). Secara umum, hasil dari uji unit root yang standar dan linier, Zivot dan Adrews (ZA) dan Lumsdaine dan Papell (LP) menunjukkan bahwa IHSG memiliki perilaku pergerakan harga yang acak. Selain itu, adanya patahan struktural diidentifikasi oleh uji ZA dan LP yang berhubungan dengan peristiwa liberalisasi pasar keuangan dan krisis keuangan. Prosedur uji unit root nonlinier gagal untuk menolak nul hipotesis unit root untuk semua indeks, menunjukkan bahwa IHSG ditandai oleh proses random walk mendukung teori hipotesis pasar efisien.

Keywords: linearity and non-linearity; smooth transition autoregressive (STAR) models; stock markets; structural breaks 


\section{Introduction}

Financial markets such as bond and stock markets plays important role in promoting economic efficiency and economic growth by channeling funds from people who do not have a productive use to those who need funds for productive investment. Equally important is the information efficiency of the financial market. Market efficiency is essential because it helps to explain why asset prices change in financial markets and how these changes take place. More precisely, efficient market implies that 1) one investment is as good as any other because the securities' prices are correct; 2) a security's price reflects all available information about the intrinsic value of the security; 3) security prices can be used by managers of both financial and nonfinancial firms to assess their cost of capital (cost of financing their investments) accurately and hence that security prices can be used to help them make the correct decisions about whether a specific investment is worth making or not (Mishkin 2004). Thus market efficiency is indisputably desirable for market development and economic growth as a whole.

In an efficient market, changes of stock prices are influenced by different types of information. Fama (1970) distinguishes three versions of market efficiency depending on the underlying information set that is available to market participants: weak form, semistrong form and strong form. Markets are said to be weak form efficient if the current stock prices fully reflect information contained in the past realizations of the price. In an efficient market, stock prices only response unpredictable news, news are random, thus stock price changes should be also unpredictable and random and one cannot earn abnormal returns on the basis of historical infor- mation on prices and trading volumes. Stock prices are characterized by a unit root if stock prices follow a random walk. Thus, testing for a unit root in stock prices is one way to validate the weak form efficiency hypothesis.

Over the years, there has been a large body of empirical research concerning the validity of the efficient market hypothesis with respect to stock markets in both developed and developing countries. Empirical research on testing the random walk hypothesis has produced mixed results. For instance, Fama and French (1988), Lo and MacKinlay (1988); Poterba and Summers (1988); Urrutia (1995); Grieb and Reyes (1999); Chaudhuri and Wu (2003); Shively (2003); Narayan (2008) have found that stock indexes are not characterized by a unit root. In contrast, others studies have found stock prices are characterized by a unit root process. For instance, Hubber (1997); Lee (1992); Ozdemir (2008); Narayan (2005); Narayan and Smyth (2005); Qiant et al. (2008).

As far as the emerging markets are concerned, it is widely believed that the majority of emerging markets are less efficient than developed markets due to certain market imperfections such as transaction costs, poor quality of information disclosures, thin trading, and inadequate financial and accounting regulations. For this reason, recent studies on emerging markets have mainly stressed the weak form efficiency whereas the literature on developed markets is concerned by all three forms of efficiency. The empirical evidence is also inclusive for the developing countries. These studies on emerging stock markets can be divided into two groups depending on findings. Researches who finds the evidence to support the weak-form efficiency [e.g., (Urrutia 1995); (Ojah and Karemera 1999); (Abrosimova et al. 2005); (Moustafa 2004)], and others shows the evidence of pre- 
dictability or rejection of the random walk hypothesis in stock returns [e.g., (Huang 1995); (Poshakwale 1996); (Mobarek and Keasey 2002); (Khaled and Islam 2005)].

Considering the theoretical and practical significance, the testable implications and conflicting empirical evidence of the random walk hypothesis motivates us to have a fresh look at this issue of weak-form efficiency in the context of an emerging market, namely Indonesian stock market. This study is potentially interesting case study for a developing capital market, which shares most of the characteristics of a typical emerging market. Secondly, the liberation of financial market and advance on technology, these markets become more integrated with global equity markets, which attracting more international investors in the hope to benefit from higher abnormal returns and portfolio diversification, where market efficiency has important implications for those investors. Thirdly, the majority of previous studies apply the traditional unit root test in testing the null hypothesis of a unit root in stock prices. It is well known that the tradition test may bias in not rejecting the null hypothesis in the presence of structure breaks (Perron 1989). Chauduri and Wu (2003), Narayan and Smyth, (2004), Narayan (2005), Lean and Smyth (2007), Narayan (2008); Lee et al. (2010) investigate the stationarity properties using the new unit test with structure breaks for other markets.

Furthermore, economic theory suggests that the behavior of stock prices may exhibit nonlinear pattern in the series due to transaction costs and market frictions, heterogeneity of agent's investment objectives, and diversity in agent beliefs (Hasavov 2009). ${ }^{1}$
Therefore the reliability of the finding from existing studies assuming linearity in the time series is questionable. To this end, some researcher then adopt to Narayan (2005); Munir and Mansur (2009) investigate the random walk hypothesis in the stock market by adopting nonlinear threshold autoregressive (TAR) model of Caner and Hansen (2001). Furthermore, Hasanove and Omay (2007) and Hasanov (2009) are among the studies that examine the random walk hypothesis by adopting nonlinear unit root test procedure proposed by Kapetanios et al. (2003).

As far as Indonesian stock is concerned, limited empirical studies are available yet the results are mixed. While Huang (1995), Huang and Yang (1995), Groenwold and Ariff (1998) Karemera et al. (1999) find the Indonesian stock weak-form efficient, Magnusson and Higgs (2005), Fuss (2005), Kim and Shamsuddin (2006), Hoque et al. (2006) and Zulfadin (2008) find that the market is weakform inefficiency. Given Indonesian has gone through financial liberation, and financial crisis that may cause structural breaks. Previous studies did not take structure breaks into consideration. Furthermore, previous studies are based on the assumption of linear data generating process. Therefore the reliability of the finding from existing studies is questionable.

Thus, this paper attempts to overcome the above mentioned problems and contributes to the existing literature on the Indonesian stock market efficiency by taking both structural breaks and the nonlinearity into consideration. More specifically, this paper contributes to exiting literature on random walk hypothesis for Indonesian stock market

${ }^{1}$ See, Brock and Lebaron (1996), Brock and Hommes (1998), Peters (1994), Guillaume et al. (1995), Dumas (1992); Shleifer (2000), Hong and Stein (1999), among others 
in four novel ways. Firstly, in addition to the conventional unit root test, the Zivot and Andrew (1992) one break and the Lumsdaine and Papell (1997) two-break unit root tests are used. Secondly, we employ the powerful linearity test proposed by Harvey et al. (2008) which is applicable when the order of integration of the time series under investigation is uncertain. It reveals that the Indonesian Stock index is nonlinear process in which allow us to question the validity of linear unit root test. Thirdly, we use nonlinear STAR unit root test developed by Kapetanios et al. (2003) and Kruse (2010) which allows for testing unit root behavior in a more general nonlinear framework where the transition between regimes occurs in a smooth manner, rather than instantaneously. Finally, we also estimate the speed of transition parameter. The estimated ESTAR model indicates that the Indonesian stock market is not mean reversion process.

The rest of the study is organized as follows: Section two briefly describe about the methodology employed in the study. Data on which analysis is based is then presented in Section 3. Section 4 in turns discusses the empirical results and some implications of the study. Finally, Section 5 concludes the study.

\section{Methodology}

\section{Unit Root Test With One Structural Break}

According to Perron (1989), if structural break exist, the power to reject a unit root decreases when the stationary alternative is true and the structural break is ignored.
Therefore, Perron (1989) then developed three alternative models, which accommodate a break in the trend function, namely: a) The crash model, which allows for a one time structural break in the intercept of the trend function; b) The changing growth model, which allows for a structural break in the slope; c) The crash-cum-growth model, which allows for a structural break in the intercept and slope.

However, Zivot and Andrews (1992) have argued that selecting the break point a priori based on ex post examination or knowledge of the data, as developed by Perron (1989) could lead to an over rejection of the unit root hypothesis. Hence, to avoid spurious results the break date is also treated as being endogenous. To this end, Zivot and Andrews (1992) developed two versions of the sequential trend break model to investigate the unit root hypothesis, as follows:

Model A:

$$
\begin{aligned}
\Delta Y_{t}= & \alpha_{0}+\alpha Y_{t-1}+\beta_{t}+\theta D U_{t}+ \\
& \sum_{j=1}^{k} d_{j} \Delta Y_{t-j}+\varepsilon_{t} \ldots \ldots \ldots \ldots \ldots \ldots . . .
\end{aligned}
$$

Model C:

$$
\begin{aligned}
& \Delta \mathrm{Y}_{\mathrm{t}}=\alpha_{0}+\alpha \mathrm{Y}_{\mathrm{t}-1}+\beta_{\mathrm{t}}+\theta \mathrm{DU}_{\mathrm{t}}+\gamma \mathrm{DT}_{\mathrm{t}}+ \\
& \sum_{j=1}^{k} d_{j} \Delta Y_{t-j}+\varepsilon_{t}
\end{aligned}
$$

The null hypothesis for model 1 and 2 is that $\alpha=0$, which implies there is a unit root in $\mathrm{Y}_{\mathrm{e}}$, against the alternative hypothesis $\alpha<0$, which implies that $Y_{t}$ is breakpoint stationary. Where $\mathrm{DU}_{\mathrm{t}}$ is an indicator dummy variable for a mean shifting occurring at time $\mathrm{TB}$, while DT is the corresponding trend shift variable, where: 


$$
\mathrm{DU}_{\mathrm{t}}=\left\{\begin{array}{l}
1 \text { if } \mathrm{t}>\mathrm{TB} \\
0 \text { otherwise }
\end{array}\right.
$$

and

$$
\mathrm{DU}_{\mathrm{t}}=\left\{\begin{array}{l}
\mathrm{t}-\mathrm{TB} \text { if } \mathrm{t}>\mathrm{TB} \\
0 \text { otherwise }
\end{array}\right.
$$

Furthermore, to implement the sequential trend break model, some region must be chosen such that the end points of the sample are not included. This is because in the presence of the end points the asymptotic distribution of the statistics diverges to infinity. Zivot and Andrews (1992) suggest the trimming region be specified as $(0.15 \mathrm{~T}, 0.85 \mathrm{~T})$, which is followed here. Thus, the break points are selected by choosing the value of TB for which the ADF t-statistic is maximized.

\section{Unit Root Test with Two Structural Breaks}

A possible problem with the Zivot and Andrews (1992) test is the loss of power if there are two structural breaks in the series. In response to this condition, Lumsdaine and Papell (1997) proposed the extension of Zivot and Andrews (1992) model A and C to allow for two structural breaks. Lumsdaine and Papell (1997) then call these models AA and CC respectively. Model AA allows for two breaks in the intercept of the trend and model CC allows for two breaks in the intercept and slope of the trend. Model AA can be represented as follows:

$$
\begin{aligned}
\Delta \mathrm{Y}_{\mathrm{t}}= & \alpha_{0}+\alpha \mathrm{Y}_{\mathrm{t}-1}+\beta_{\mathrm{t}}+\theta D \mathrm{U}_{\mathrm{t}}+\omega \mathrm{DU} \mathrm{U}_{\mathrm{t}}+ \\
& \sum_{\mathrm{j}=1}^{\mathrm{k}} \mathrm{d}_{\mathrm{j}} \Delta \mathrm{Y}_{\mathrm{t}-\mathrm{j}}+\varepsilon_{\mathrm{t}} \ldots \ldots \ldots \ldots \ldots \ldots . . .(3)
\end{aligned}
$$

Model CC takes the following form:

$$
\begin{aligned}
\Delta \mathrm{Y}_{\mathrm{t}}= & \alpha_{0}+\alpha \mathrm{Y}_{\mathrm{t}-1}+\beta_{\mathrm{t}}+\theta \mathrm{DU}_{\mathrm{t}}+\gamma \mathrm{DT} \mathrm{T}_{\mathrm{t}}+ \\
& \omega \mathrm{DU} 2_{\mathrm{t}}+\Psi \mathrm{PT} 2 \sum_{\mathrm{t} j=1}^{\mathrm{k}} \mathrm{d}_{\mathrm{j}} \Delta \mathrm{Y}_{\mathrm{t}-\mathrm{j}}+\varepsilon_{\mathrm{t}}
\end{aligned}
$$

The null and alternative hypotheses are the same as in the one break case. DU1 and $\mathrm{DU} 2_{t}$ are indicator dummy variables for a mean shift occurring at TB1 and TB2 respectively, where TB2 $>$ TB1 +2 and DT1 $1_{t}$ and DT $2_{2}$ are the corresponding trend shift variables:

$$
\begin{aligned}
& \text { DU1 }{ }_{\mathrm{t}} \begin{cases}1 & \text { if } \mathrm{t}>\mathrm{TB} 1 \\
0 & \text { otherwise }\end{cases} \\
& \mathrm{DU}_{\mathrm{t}} \begin{cases}1 & \text { if } \mathrm{t}>\mathrm{TB} 2 \\
0 & \text { otherwise }\end{cases}
\end{aligned}
$$

and

$$
\begin{aligned}
& \mathrm{DU} 1_{\mathrm{t}}= \begin{cases}\mathrm{t}-\mathrm{TB} 1 & \text { if } \mathrm{t}>\mathrm{TB} 1 \\
0 & \text { otherwise }\end{cases} \\
& \mathrm{DU} 2_{\mathrm{t}}= \begin{cases}\mathrm{t}-\mathrm{TB} 1 & \text { if } \mathrm{t}>\mathrm{TB} 1 \\
0 & \text { otherwise }\end{cases}
\end{aligned}
$$

The same trimming region is used as in the case of model $\mathrm{A}$ and $\mathrm{C}$. The critical values are calculated using the same methodology as in the case of model A and C.

\section{Nonlinear Unit Root Test of Kapetanios et al. (2003)}

Consider a univariate smooth transition autoregressive (STAR) model of order one:

$$
\begin{aligned}
& \mathrm{y}_{\mathrm{t}}=\beta \mathrm{y}_{\mathrm{t}-1}+\gamma \mathrm{y}_{\mathrm{t}-1} \mathrm{~F}\left(\theta ; \mathrm{y}_{\mathrm{t}-\mathrm{d}}\right)+\varepsilon_{\mathrm{t}} \\
& \mathrm{t}=1, \ldots \mathrm{T}
\end{aligned}
$$


where $y_{t}$ is a mean zero stochastic process and $e_{t}$ i.i.d. $\left(0, \sigma^{2}\right)$, and $\beta$ and $\gamma$ are unknown parameters. The transition function is assumed to be of the exponential form:

$$
\mathrm{F}\left(\theta ; \mathrm{y}_{\mathrm{t}-\mathrm{d}}\right)=1-\exp \left(-\theta_{\mathrm{y}^{\mathrm{t}-\mathrm{d}}}^{2}\right)
$$

Where it is assumed that $\theta>0$ and $d \geq 1$ is the delay parameter. The exponential function is bounded between zero and one, i.e. $F: R \rightarrow[0,1]$ has the properties $F(0)=0$; $\lim _{x \rightarrow \pm \infty} F(x)=1$ and is symmetrically U-shaped around zero. The parameter $\theta$ is slope coefficient and determines the speed of transaction between to regimes that correspond to extreme values of the transition function. Substituting (6) into (5) one obtains the following exponential STAR (ESTAR) model:

$$
\mathrm{y}_{\mathrm{t}}=\beta \mathrm{y}_{\mathrm{t}-1}+\theta \mathrm{y}_{\mathrm{t}-1}\left[1-\exp \left(-\theta_{\mathrm{y}_{\mathrm{t}-\mathrm{d}}}^{2}\right)\right]+\varepsilon_{\mathrm{t}} \ldots \ldots .(7)
$$

Subtract $y_{t-1}$ from both side of (3), we have:

$$
\mathrm{y}_{\mathrm{t}}=\phi \mathrm{y}_{\mathrm{t}-1}+\gamma \mathrm{y}_{\mathrm{t}-1}\left[1-\exp \left(-\theta \mathrm{y}_{\mathrm{t}-\mathrm{d}}^{2}\right)\right]+\varepsilon_{\mathrm{t}}
$$

where $\phi=\beta-1$. The ESTAR model has a nice property that it allows modeling different dynamics of series depending on the size of the deviations from the fundamental equilibrium (Teräsvirta 1994; Michael et al. 1997).

The theory suggests that arbitrageurs shall not engage in reversion strategies if deviations from the equilibrium are small in size (arbitrage is not profitable). If the deviations from equilibrium are large enough, however, arbitrageurs shall engage in profitable reversion trading strategies, and thus bring the prices to their equilibrium levels. In the context of ESTAR model, this would imply that while $\phi \geq 0$ is possible, one must have $\gamma<0$ and $\phi+\gamma<0$ for the process to be globally stationary. Under these conditions, the process might display unit root for small values of $\mathrm{y}_{\mathrm{t}-\mathrm{d}}^{2}$, but for larger values of, it has stable dynamics, and as a result, is geometrically ergodic. Furthermore, the speed of mean reversion increases with the size of deviation from the fundamental equilibrium.

Following the practice in the literature (Balke and Fomby 1997 in the context of TAR models and Michael et al 1997 in the context of ESTAR models), Kapetanios et al. (2003) further impose, implying that follows a unit root in the middle regime. The reason is that, in some economic contexts it is reasonable to assume that the variable displays a mean reverting behavior towards an attractor when it is sufficiently far away from it, but a random walk representation in the neighborhood of the attractor. In this case, the ESTAR model can be written as:

$$
\Delta \mathrm{y}_{\mathrm{t}}=\gamma \mathrm{y}_{\mathrm{t}-1}\left[1-\exp \left(-\theta \mathrm{y}_{\mathrm{t}-\mathrm{d}}^{2}\right)\right]+\varepsilon_{\mathrm{t}}
$$

The global stationarity of the process can be established by testing the null hypothesis $H_{0}: \theta=0$ against the alternative $H_{0}: \theta>$ 1. However, testing the null hypothesis directly is not feasible since the parameter is not identified under the null. To overcome this problem, Kapetanios et al. (2003) follow suggestion of Luukkonen et al. (1988) to replace the transition function by its appropriate Taylor approximation to derive a $t$ type test statistic. Replacing the transition function with its first order Taylor approximation yields the following auxiliary regression:

$$
\Delta \mathrm{y}_{\mathrm{t}}=\delta \mathrm{y}_{\mathrm{t}-1}^{3}+\varepsilon_{\mathrm{t}}
$$

where $e_{t}$ comprises original shocks $\varepsilon_{t}$ as well as the error term resulting from Taylor ap- 
proximation. The test statistic for $\delta=0$ against $\delta<0$ is obtained as follows:

$$
\mathrm{t}_{\mathrm{NL}}=\hat{\delta} / \text { s.e. }(\hat{\delta}) .
$$

where,

$\delta=\quad$ the OLS estimate, and

s.e. $(\hat{\delta})=$ the standard error of $\delta$.

The asymptotic distribution of this test $t_{N L}$ is non-standard and KSS (2003) derive it and provide asymptotic critical values.

To accommodate stochastic processes with nonzero means and/or linear deterministic trends, the following modifications are needed. In the case where the data has nonzero mean, i.e., $x_{t}=\mu+y_{p}$ one must replace the raw data with de-meaned data $y_{t}=x_{t}-x$ where $\bar{x}$ is the sample mean. In the case where the data has a nonzero mean and a nonzero linear trend, i.e., $x_{t}=\mu+\alpha t+y_{p}$ one must instead use the de-meaned and de-trended data $y_{t}=x_{t}-\hat{\mu}-\hat{\alpha} t$ where $\hat{\mu}$ and $\alpha$ are ordinary least square (OLS) estimators of $\mu$ and $\alpha$. If errors in (10) are serially correlated, one may augment (9) and (10) into following:

$$
\Delta \mathrm{y}_{\mathrm{t}}=\sum_{\mathrm{j}=1}^{\mathrm{p}} \rho j \Delta \mathrm{y}_{\mathrm{t}-1}+\gamma \mathrm{y}_{\mathrm{t}-1}\left[1-\exp \left(-\theta \mathrm{y}_{\mathrm{t}-\mathrm{d}}^{2}\right)\right]+\varepsilon_{\mathrm{t}}
$$

$$
\Delta y_{t}=\sum_{j=1}^{p} \rho j \Delta y_{t-j}+\delta y_{t-d}^{3}+\varepsilon_{t}
$$

In practice, the number of augmentations $p$ and the delay parameter $d$ must be selected prior to the test. Kapetanios et al. (2003) propose that standard model selection criteria or significance testing procedure be used for selecting the number of augmentations $p$. They also suggest that the delay pa- rameter $\mathrm{d}$ be chosen to maximize goodness of fit over $\mathrm{d}-\left\{1,2, \ldots \mathrm{d}_{\max }\right\}$. However, in practice, $\mathrm{d}$ is set to be one, see for example, Kapetanios et al. (2003) and Daiki (2005, 2006).

However, Kapetanios et al. (2003) test assumes that the location parameter $c$ in the smooth transition function is equal to zero. According to Kruse (2010) when relaxing this assumption, we are faced with a nonstandard testing problem. Since standard inference $c$ techniques are not appropriate in this situation, Kruse (2010) then proposed new approach to allow for a non-zero location parameter $\mathrm{c}$ in the exponential transition function. Following Kapetanios et al. (2003), Kruse (2010) applies a first order Taylor approximation to $G\left[y_{\hat{t}} \gamma, c=\left(1-\exp \left\{-\gamma\left(y_{t-1}-c\right]^{2}\right\}\right)\right.$ around $\gamma=0$ and proceed with the test regression:

$$
\Delta \mathrm{y}_{\mathrm{t}}=\beta_{1} \mathrm{y}_{\mathrm{t}-1}^{3}+\beta_{2} \mathrm{y}_{\mathrm{t}-1}^{2}+\beta_{3} \mathrm{y}_{\mathrm{t}-1}+\mathrm{u}_{\mathrm{t}} \ldots
$$

Following Kapetanios et al. (2003) he impose $\beta_{3}=0$ to improve the power of the test, hence we proceed with:

$$
D y_{t}=b_{1} y_{t-1}^{3}+b_{2} y_{t-1}^{2}+u_{t}
$$

where $\beta_{1}=\gamma \phi$ and $\beta_{2}=2 c \gamma \phi$. Kruse (2010) interested in the pair of hypotheses given by $H_{0}: \gamma=0$ against $H_{1}: \gamma>0$. In the regression (15), this pair of hypothesis is equivalent to $H_{0}: \beta_{1}=\beta_{1}=0$ against $H_{1}: \beta_{1}<0, \beta_{2} \neq 0$. Note that the two-sidedness of $\beta_{2}$ under $H_{1}$ stems from the fact that $\mathrm{c}$ is allowed to take real values. This testing problem is nonstandard in the sense that one parameter is one sided under $\mathrm{H}_{1}$ while the other is two-sided. A standard Wald test would be inappropriate and he therefore applies the methods of Abadir and Distaso (2007) to derive a suit- 
able test. In a nutshell, the one-sided parameter is orthogonalized with respect to the two sided one. The modified Wald test builds upon the one-sided parameter $\left(\beta_{1}\right)$ and the transformed two-sided parameter, say $\beta \frac{1}{2}$, that are stochastically independent by definition.

Let the parameter vector of the regression model (15) be $\theta=\left[\beta_{1} \beta_{2}\right]^{\prime}$. Following the notation of Abadir and Distaso (2007), the null hypothesis of a unit root is written as:

$$
\begin{aligned}
H_{0}: h(\theta) \equiv & {\left[h_{1}(\theta) h_{2}(\theta)\right]^{\prime}-} \\
& {\left[\begin{array}{ll}
b 1 & b 2
\end{array}\right]^{\prime}-\left[\begin{array}{ll}
0 & 0
\end{array}\right]^{\prime} }
\end{aligned}
$$

The alternative hypothesis of a globally stationary ESTAR model is given by:

$H_{1}: h_{1}(\theta)<0$ or $h_{2}(\theta) \neq 0$

which includes the subset hypothesis $H_{1} \cap h_{1}(\theta)<0$ and $h_{2}(\theta) \neq 0$. Theorem 6 in Abadir and Distaso (2007) states that the modified Wald test is consistent against $\mathrm{H}_{1}$ as well as $H_{1}$.

Kruse (2010) then modified the standard Wald test statistic based on the Hessian matrix. Hence, now we have the new test statistic for the unit root hypothesis against globally stationary ESTAR. A simpler and more intuitive way to formulate the statistic is:

$\tau=\mathrm{t}_{\beta \frac{1}{2}=0}^{2}+1\left(\hat{\beta}_{1}<0\right) \mathrm{t}_{\beta_{1=0}^{2}}$

The two summands appearing in the test statistic $\tau$ can be interpreted as follows: the first term is a squared t-statistic for the hypothesis $\beta \frac{1}{2} \equiv \beta_{1}-\beta_{1} v_{21} / v_{11}$ with $\beta \frac{1}{2}$ being orthogonal to $\beta$. Additionally, the second term is a squared t-statistic for the hypothesis $\beta_{1}=$
$O$, the one-sidedness under $H_{1}$ is achieved by the multiplied indicator function.

\section{Data Description}

This study employs monthly Jakarta Composite index (JCI) over the period April 1983 to December 2010. The index is taken from Bloomberg database through a subscription by the Kulliyyah of Economics and Management Sciences, International Islamic University Malaysia. Specifically we retrieve the closing prices of the last trading days of all months and transformed into natural logarithm.

\section{Empirical Results and \\ Discussion}

\section{Standard Linear Unit Root Test Results}

As preliminary step, the traditional unit root test such as ADF (Dickey and Fuller 1981), Phillip Perron and Kwiatkowski et al. (KPSS 1992) tests are employed, (see Table 1) indicates that the traditional unit-root tests provide no evidence of trend stationary, failing to reject the unit-root null at conventional significance levels. However, we find evidence that this variable is stationary when expressed in the first difference. Accordingly, JCI series seem to be integrated of order 1, or I (1). Hence, we can conclude that Jakarta Composite Index series behave according to random stochastic process. 
Figure 1. Plot of Monthly Closing Price of the Jakarta Composite Index and Its Transformation (Anril 1983-December 2010)

(a)

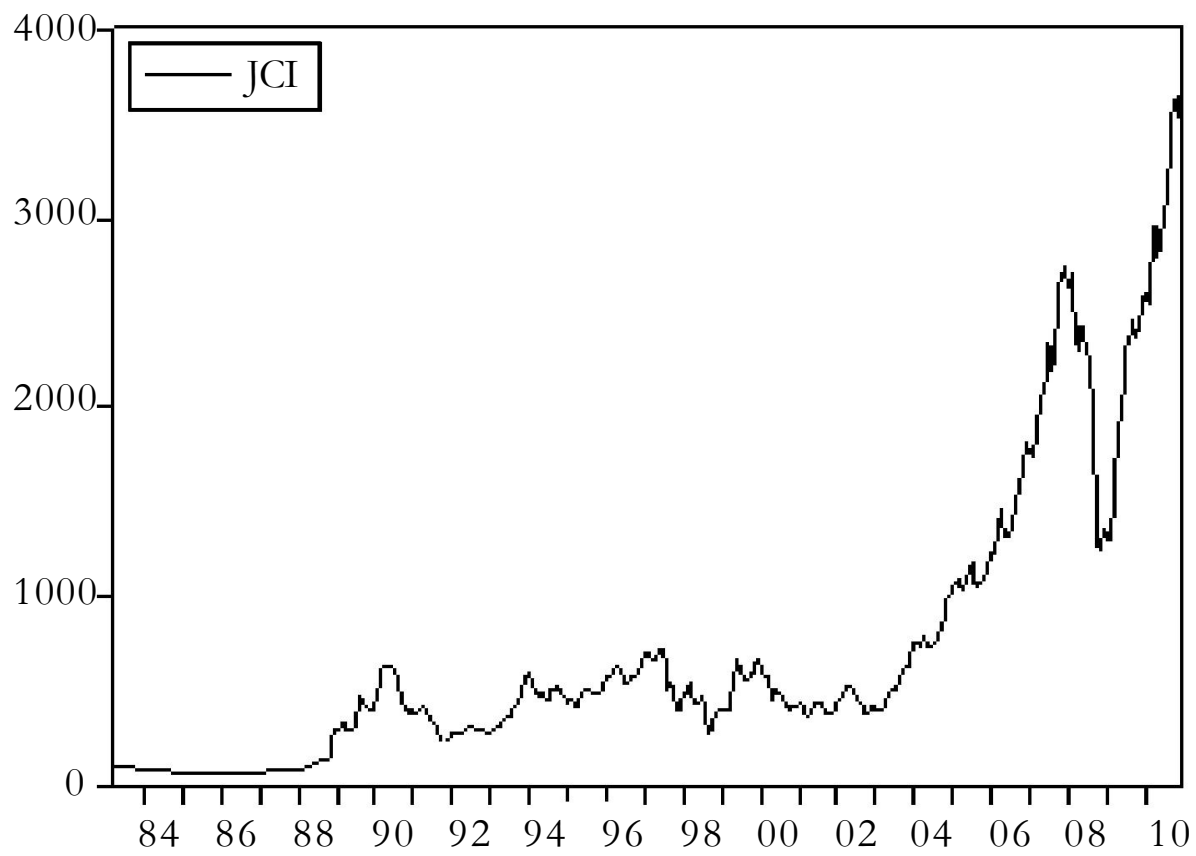

(b)

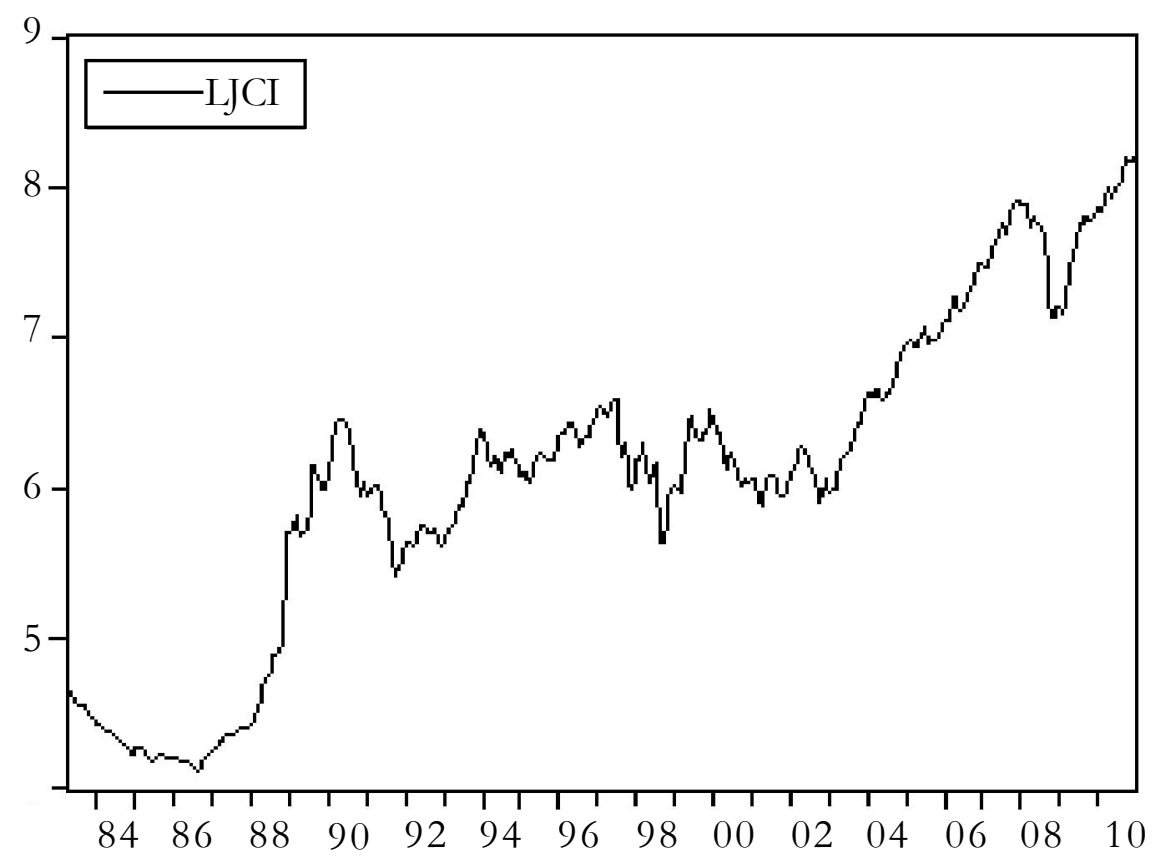


Table 1. Linear Unit Root Test on Jakarta Composite Index

\begin{tabular}{lllllll}
\hline \multirow{2}{*}{ Series } & \multicolumn{2}{c}{ ADF } & \multicolumn{2}{c}{ PP } & \multicolumn{2}{c}{ KPSS } \\
\cline { 2 - 7 } & No Trend & Trend & No Trend & Trend & No Trend & Trend \\
\hline $\operatorname{lnJCI}$ & -0.3485 & -2.1430 & -0.2529 & -2.0568 & $1.7791^{*}$ & $0.1744^{* *}$ \\
$\Delta \operatorname{lnJCI}$ & $-14.8831^{*}$ & $-14.8809^{*}$ & $-14.8975^{*}$ & $-14.8809^{*}$ & 0.0929 & 0.0687 \\
\hline
\end{tabular}

Note: $*$, and ${ }^{* *}$ denote significance at $1 \%$ and $5 \%$ level respectively

Table 2. Unit Root Test with One Structural Break on Jakarta Composite Index

\begin{tabular}{lcc}
\hline & Model A & Model C \\
\cline { 2 - 3 } TB & $10 / 1988$ & $10 / 1988$ \\
$\mathbf{A}$ & -0.1083 & -0.1064 \\
& {$[-3.0265]$} & {$[-2.9393]$} \\
$\Gamma$ & $0.0567 * *$ & $0.0482^{* * *}$ \\
& {$[2.4670]$} & {$[1.5045]$} \\
$\Gamma$ & - & -0.0003 \\
& & {$[-0.3779]$} \\
$\boldsymbol{k}$ & 8 & 8 \\
Critical values & & \\
for ${ }_{\alpha}$ & & \\
$\mathbf{1} \%$ & -5.34 & -5.57 \\
$\mathbf{5 \%}$ & -4.80 & -5.08 \\
$\mathbf{1 0} \%$ & -4.58 & -4.82 \\
\hline
\end{tabular}

Notes: The optimum lag length $k$ is selected according to Schwarz Information Criteria (SIC). Model A refers to structural break in the intercept only

$\Delta \mathrm{Y}_{\mathrm{t}}=\mathrm{k}+\alpha \mathrm{Y}_{\mathrm{t}-1}+\beta \mathrm{t}+\theta \mathrm{DU}_{\mathrm{t}}+\Sigma_{\mathrm{j}}^{\mathrm{k}}=$ $1 \mathrm{~d}_{\mathrm{j}} \Delta \mathrm{Y}_{\mathrm{t}-1}+\varepsilon_{\mathrm{t}}$, and model $\mathrm{C}$ refers to structural breaks both in the intercept and slope of the trend function $\Delta \mathrm{Y}_{\mathrm{t}}=\mathrm{k}+\alpha \mathrm{Y}_{\mathrm{t}-1}+\beta_{\mathrm{t}}+\gamma \mathrm{D} \mathrm{T}_{\mathrm{t}}$ $+\omega \mathrm{DU} 2_{\mathrm{t}}+\omega \mathrm{DT} 2 \mathrm{t}+\psi \mathrm{DT} 2 \mathrm{t} \sum_{\mathrm{j}}^{\mathrm{k}}=$ $1 \mathrm{dj} \Delta \mathrm{Y}_{\mathrm{t}-\mathrm{j}}+\varepsilon_{\mathrm{t}}$. Number in parentheses are $t$-statistics. $* * *$ and $* * *$ denote significance at 1 percent, 5 percent and 10 percent level respectively.

\section{Zivot and Andrews (1992) One Structural Break Test}

Table 2 reports the Zivot and Andrews (ZA) test results for Jakarta Composite Index. Table 2 clearly reveals that the null of unit root hypothesis still cannot be rejected for series of Jakarta Composite Index even after the structural breaks is allowed. It can be identified from the estimated test statistics of $\alpha(-3.0265)$ which is greater than ZA critical value for all significance level. While for model $\mathrm{C}$ also indicating the same results, where the test statistics of coefficient $\alpha$ (2.9393 ) is greater than ZA critical value, fail to reject null hypothesis of non-stationary.

Furthermore, from the estimated coefficient of $\theta$ in model A the break in the intercept is found to be statistically significant at the 5 percent level (based on critical value from the standard normal distribution). While for model $\mathrm{C}$ it is found that estimated coefficient of $\theta$ is statistically significant at 10 percent level, implying the Jakarta Composite Index series exist at least one structural break in the intercept. The break date provided by model A and C is during October 1988. Period of 1987-1988 is corresponds to the issuance of PAKDES (December Package) 87 to give ways for companies to go public and foreign investors to invest their money in Indonesia. Furthermore, in December 1988, the government issued PAKDES 88 to encour- 
age companies go public and some other regulations that brought positive impacts on the capital market growth.

\section{Lumsdaine and Papell (1997) Two Structural Breaks Test}

We now consider the case in which the series assumed to contain two structural breaks, with the break point determined endogenously. We estimate model AA and CC and compute the $t$-statistic for testing the level of significant for each parameter. Table 3 presents the test results, with $t$-ratios exhibited in parentheses. Several observations can be drawn from Table 3.

Model AA in the Table 3 provides strong evidence that by allowing for two structural breaks it is still not possible to reject the unit root null hypothesis, indicated from the statistical value of the estimated coefficient $\alpha$ (-4.0574) which is greater than LP critical value at all significant level. While, the results obtained from model CC indicate that Jakarta Composite Index is characterized by unit root process, it can be seen from the statistical value of $\alpha(-5.1812)$ which is greater than critical value of LP test for all significant level. These results support the existence of random walk process in the Jakarta Composite Index.

In addition, according to model AA the estimated coefficient of $\theta$ and $\omega$ are statistically significant at 1 percent level (based on critical value from the standard normal distribution), implying that in the stock price series there exist at least two structural breaks in trend. While according to model CC, we found that first break in the slope is statistically significant at 1 percent, this results indicated from the statistical value of $\theta$ (4.9237). For the second break, we have significant break in the slope at 5 percent sig- nificant level and break in the intercept at 1 percent level of significant, as indicated from the statistical value of $\omega$ (2.5550) for break in the slope and statistical value $\psi(4.6856)$ for break in the intercept.

Table 3. Unit Root Test with Two Structural Break on Jakarta Composite Index

\begin{tabular}{lcc}
\hline & Model A & Model C \\
\cline { 2 - 3 } TB1 & $10 / 1988$ & $08 / 1988$ \\
TB2 & $08 / 2004$ & $01 / 2000$ \\
$\mathbf{A}$ & -0.1908 & -0.0958 \\
$\boldsymbol{\Theta}$ & {$[-4.0574]$} & {$[-5.1812]$} \\
& $0.2814^{*}$ & $0.1524^{*}$ \\
$\boldsymbol{\Omega}$ & {$[3.6508]$} & {$[4.9237]$} \\
& $0.1664^{* *}$ & $-0.0602^{* *}$ \\
$\Gamma$ & {$[2.6690]$} & {$[-2.5550]$} \\
& - & -0.0003 \\
$\boldsymbol{\Psi}$ & & {$[-1.2857]$} \\
& - & $0.0017 *$ \\
$\boldsymbol{K}$ & 8 & {$[4.6856]$} \\
Critical values & for $\mathrm{t}_{\alpha}$ & 8 \\
$\mathbf{1 \%}$ & -6.94 & -7.34 \\
$\mathbf{5 \%}$ & -6.24 & -6.82 \\
$\mathbf{1 0 \%}$ & -5.96 & -6.49 \\
\hline
\end{tabular}

Notes: The optimum lag length $k$ is selected according to Schwarz Information Criteria (SIC). Model A refers to structural break in the intercept only $\Delta \mathrm{Y}_{\mathrm{t}}=\mathrm{k}+\alpha \mathrm{Y}_{\mathrm{t}}$ ${ }_{1}+\beta \mathrm{t}+\theta \mathrm{DU}_{\mathrm{t}}+\omega \mathrm{DU}_{\mathrm{t}}+\sum_{\mathrm{j}}^{\mathrm{k}}=1 \mathrm{~d}_{\mathrm{j}} \Delta \mathrm{Y}_{\mathrm{t}-1}+\varepsilon_{\mathrm{t}}$ and model CC refers to structural breaks both in the intercept and slope of the trend function $\Delta \mathrm{Y}_{\mathrm{t}}=\mathrm{k}+\alpha \mathrm{Y}_{\mathrm{t}-1}$ $+\beta_{\mathrm{t}}+\theta \mathrm{DU}_{\mathrm{t}}+\gamma \mathrm{DT}_{\mathrm{t}}+\omega \mathrm{DU} 2_{\mathrm{t}}+\psi \mathrm{DT} 2 \mathrm{t} \sum_{\mathrm{j}}^{\mathrm{k}}=$ $1 \mathrm{dj} \Delta \mathrm{Y}_{\mathrm{t}-\mathrm{j}}+\varepsilon_{\mathrm{t}}$. Number in parentheses are $t$-statistics. $*, * *$ and ${ }^{* * *}$ denote significance at 1 percent, 5 percent and 10 percent level respectively. 
Furthermore, the statistically significant structural break in the model AA is happened during October 1988 and August 2004, while for model CC is happened during August 1988 and January 2000. As discussed in the Zivot and Andrews (1992) model, the first structural break for model AA and CC for JCI series is October 1988 and August 1988, corresponds to some important policies made by Indonesian stock market authorities. PAKTO (October Package) 88 designed for the banking sector, but having an impact on the development of capital markets. PAKTO 88 contains provisions on $3 \mathrm{~L}$ (Legal, Lending, Limit), and the imposition of tax on deposit interest. The imposition of this tax had a positive impact on the development of capital markets. Because with the release of this policy means the government gives equal treatment between the banking sector and capital market sectors. Followed by the issuance of PAKDES 88, this package basically gives further impetus to the capital market by opening opportunities for the private sector to hold the stock. Prior to these two policies, on June 1988 Indonesia Pararel Bourse started to operate and managed by the securities and money trading organization, it consisted of brokers and dealers. Because these three policies Indonesian stock market became active capital markets for the period 1988 to the present. On the other hands, during October 1987 stock market around the world crashed, shedding a huge value in a very short time. Major indexes of market valuation in the United States dropped 30 percent or more. This was the greatest loss Wall Street had ever suffered on a single day. ${ }^{2}$

The second break for model CC is January 2000, where during 2000 Indonesian stock market experienced a negative trend, due to the political and economic instability after general election on the late of 1999. The negative trend was ended after 2003-2004 period as indicated from the second break of model AA which is happened on August 2004. As we can see from the plot graph in the Appendix, starting from this period Jakarta composite index went up continued until the end of 2007 where the global financial crisis started to attack Indonesian capital market.

\section{Linearity Test}

Before we perform the nonlinear unit test, we investigate whether we can reject the linear autoregressive model in favor of nonlinear model. The existing tests of the null of linearity against a nonlinearity alternative in the literature such proposed by Luukkonen et al. (1998), Granger and Teräsvirta (1993) and Teräsvirta (1994), however, rely on an assumption of $\mathrm{I}(0)$ behavior in the underlying series. In this study, we employ linearity test newly developed by Harvey et al. (2008). This test, the $W_{\lambda}$ test, does not require an $a$ priori assumption as to the order of integration of the process. Using this test, we obtain $W_{\lambda}=0.7 .24$ which is significant at the 5 percent level suggesting that the linearity is rejected.

${ }^{2}$ http://hnn.us/articles/895.htmld 
Table 4. Nonlinear Unit Root Test on Jakarta Composite Index

\begin{tabular}{lcccc}
\hline & \multicolumn{2}{c}{ Demeaned Series } & \multicolumn{2}{c}{ De-trended Series } \\
\cline { 2 - 5 } & \multicolumn{1}{c}{ KSS } & $\mathbf{T}$ & KSS & $\tau$ \\
\hline $\mathbf{t}_{\mathrm{NL}} / \tau$ & -0.11020 & 1.269 & -2.01698 & 4.172 \\
$\boldsymbol{\theta}$ & 0.00658 & & 0.00432 & \\
$\mathbf{S E}$ of $\hat{\boldsymbol{\theta}}$ & 0.00509 & & 0.00323 & \\
$\mathbf{C r i t i c a l}$ values of the $\mathbf{t}_{\mathrm{NL}}$ and $\boldsymbol{\tau}$ statistic & & & \\
$\mathbf{1} \%$ & -3.48 & 13.75 & -3.93 & 17.10 \\
$\mathbf{5 \%}$ & -2.93 & 10.17 & -3.40 & 12.82 \\
$\mathbf{1 0 \%}$ & -2.66 & 8.60 & -3.13 & 11.10 \\
\hline
\end{tabular}

Notes: Asymptotic critical values of the $t_{\mathrm{NL}}$ statistic are taken from Table 1, Kapetanios et al. (2003). Asymptotic critical values of the $\tau$ statistic are taken from Table 1, Kruse (2010).

\section{Nonlinear unit root test of Kapetanios et al. (2003)}

Having established the evidence of nonlinearity based on the Harvey et al. (2008) test, we use the test of Kapetanios et al. (2003) as well as Kruse (2010) where the null of a linear unit root process is tested against the alternative of a globally stationary nonlinear ESTAR model. The estimated results of nonlinear unit root test base on equation (13) and (18) for Jakarta Composite Index are presented in Table 4 . Table 4 reveals, the null hypothesis of unit root could not be rejected for both demeaned and de-trended series, indicated from the value of $t_{N L}$ which is greater than $t_{N L}$ critical value for all significance level. In line with the results form KSS test, the Kruse (2010) test also cannot reject the null hypothesis of unit root giving the value of $\tau$ test which is less than their critical value. In addition, the estimates of transition parameters $\theta$ for both series are also insignificant, indicating that no mean reversion for the series under consideration. This is an expected result since under the null hypothesis that $\theta=$ 0 , the series follow a unit root.

\section{Conclusions}

This study investigates the behavior of Indonesian stock market using various statistical tools. The results from the conventional unit root test with and without structural breaks indicate that the stock market is characterized by a unit root process. Further nonlinear test revealed that the Indonesian stock market prices follow nonlinear dynamic process. An application of the recent nonlinear unit test of KSS (2003) and Kruse (2010) both indicate that Indonesian stock market prices are consistently characterized by random walk behavior in line with the efficient market hypothesis. Furthermore, we also find that Indonesian stock market exhibit significant structural breaks.

Our finding has important implications to both academician and investment practitioners. Given the evidence that Indonesian 
stock market are characterized by nonlinear dynamic process and experienced significant structural breaks, any results from previous or future without taking structure breaks or nonlinearity may lead to an inappropriate conclusions. For investors, our findings indicates that both foreign and domestic investors could, when making their investment decisions, consider an asset price to reflect its true fundamental value at all times.

\section{References}

Abadir, K. M., and W. Distaso. 2007. Testing joint hypotheses when one of the alternatives is one-sided. Journal of Economic 140: 695-718.

Abrosimova, N., G. Dissanaike, and D. Linowski. 2005. Testing the weak-form efficiency of the Russian Stock Market. Social Science Research Network. (SSRN) Working Paper. http://papers.ssrn.com/ sol3/ papers.cfm?abstract_id $=302287$.

Balke, N. S., and T. B. Fomby. 1997. Threshold Cointegration. International Economic Review 38 (3): 627-45.

Brock, W. A., and B. D. LeBaron. 1996. A dynamic structural model for stock return volatility and trading volume. The Review of Economics and Statistics 78 (1) (February): 94-110. MIT Press.

Brock, W. A., and C. H. Hommes. 1998. Heterogeneous beliefs and routes to chaos in a simple asset pricing model. Journal of Economic Dynamics and Control 22: 1235-74.

Caner, M., and B. E. Hansen. 2001. Threshold Auto regression with a Unit Root. Econometrica, Econometric Society 69 (6) (November): 1555-1596.

Chaudhuri, K., and Y. Wu. 2003. Random walk versus breaking trend in stock prices: evidence from emerging markets. Journal of Banking and Finance 27: 575-92.

Daiki, M. 2005. The term structure of interest rates with nonlinear adjustment: Evidence from a unit root test in the nonlinear STAR framework. Economics bulletin 5: 1-7.

Daiki, M. 2006. Non-linear adjustment in the term structure of interest rates: a cointegration analysis in the non-linear STAR framework. Applied Financial Economics 11: 1301-1307.

Dickey, D., and W. Fuller. 1979. Distribution of the estimators for autoregressive time series with a unit root. Journal of the American Statistical Association 74: 427-431.

Dumas, B. 1992. Dynamic equilibrium and the real exchange rate in a spatially separated world. Review of Financial Studies 5: 153-180.

Fama, E. F. 1970. Efficient capital markets: a review of theory and empirical work. Journal of Finance 25: 383-417.

Fama, E. F. 1995. Random walks in stock market prices. Finance Analyste Journal 21: 55-59. http:// www.jstor.org/stable/4469865.

Fama, E. F., and K. R. French. 1988. Permanent and temporary components of stock prices. Journal of Political Economy 96 (2) (April): 246-273.

Fuss, R. 2005. Financial liberalization and stock price behaviour in Asian emerging market. Economic Change and Restructuring 38: 37-62. 
Grieb, T. A., and M. G. Reyes. 1999. Random walk tests for Latin American equity indexes and individual firms. Journal of Financial Research 22: 371-83.

Groenewold, N., and M. Ariff. 1998. The Effects of de-regulation on share market efficiency in the Asia Pacific. International Economic Journal 12 (4): 23-47.

Harvey, D. I., S. J. Leybourne, and B. Xiao. 2008. A powerful test for linearity when the order of integration is unknown. Studies in Nonlinear Dynamics and Econometrics 12 (2).

Hasanov, M. 2009. Is South Korea's Stock Market efficient? Evidence from a nonlinear unit root test. Applied Economics Letters 16: 163-167.

Hasanov, M., and T. Omay. 2007. Are the Transition Stock Markets Efficient? Evidence from NonLinear Unit Root Tests. Central Bank Review. Central Bank of the Republic of Turkey.

Hong, H., and J. C. Stein. 1999. A unified theory of under reaction, momentum trading, and overreaction in asset markets. Journal of Finance 54: 2143-84.

Hoque, H. A. A. B., J. H. Kim, and C. S. Pyun. 2006. A Comparison of variance ratio tets of random walk: A case of Asian emerging markets. International Review of Economics and Finance.

Huang, B-N. 1995. Do Asian stock market prices follow random walks? Evidence from the variance ratio test. Applied Financial Economics 5: 251-6.

Huang, B. N., and C. W. Yang. 1995. The Fractal Structure in Multinational Stock Returns. Applied Economics Letters 2: 67-71.

Huber, P. 1997. Stock market returns in thin markets: evidence from the Vienna stock Exchange. Applied Financial Economics 7: 493-498.

Islam, A., and M. Khaled. 2005. Tests of weak-form efficiency of the Dhaka Stock Exchange. Journal of Business Finance and Accounting 32: 1613-1624.

Kapetanios, G., Y. Shin, and A. Snell. 2003. Testing for a unit root in the nonlinear STAR framework. Journal of Econometrics 112: 359-79.

Karamera, D., K. Ojah, and J. A. Cole. 1999. Random walks and market efficiency tests: Evidence from emerging equity market. Review of Quantitative Finance and Accounting 13: 171-188.

Kim, J. H., and A. Shamsuddin. 2007. Are Asian Stock Markets efficient? Evidence from new multiple variance ratio tests. Journal of Empirical Finance 15: 518 - 532.

Kruse, R., 2010. A new unit root test against ESTAR based on a class of modified statistics. Statistical Papers. DOI: 10.1007/s00362-009-0204-1.

Kwiatkowski, D., P.C.B. Phillips, P. Schmidt, and Y. Shin. 1992. Testing the null hypothesis of stationarity against the alternative of a unit root: How sure are we that economic time series have a unit root? Journal of Econometrics 54: 159 -178.

Lean, H. H., and R. Smyth. 2007. Do Asian Stock Markets follow a random walk? Evidence from LM unit root tests with one and two structural breaks. Review of Pacific Basin Financial Markets and Policies 10: 15-31.

Lee, C. C., J. D Lee, and C. C. Lee. 2010. Stock prices and the efficient market hypothesis: Evidence from a panel stationary test with structural breaks. Japan and the World Economy 22 (1) (January): 49-58.

Lee, U. 1992. Do stock prices follow random walk? Some international evidence. International Review of Economics and Finance 1 (4): 315-27. 
Lo, A. W., and A. C. MacKinlay. 1988. Stock market prices do not follow random walks: Evidence from a simple specification test. The Review of Financial Studies 1 (1): 41-66.

Luukkonen, R., P. Saikkonen, and T. Terasvirta. 1988. Testing linearity against smooth transition autoregressive models. Biometrika 75: 491-9.

Lumsdaine, R., and D. Papell. 1997. Multiple trend breaks and the unit-root hypothesis. Review of Economics and Statistics 79: 212-218.

MacKinnon, J. 1991. Critical values for cointegration tests. In: Engle R,Granger C. (eds) Long-Run Economic Relationships: Readings in Cointegration. Oxford University Press, Oxford: 267-276.

Michael, P., R. A. Nobay, and D. A. Peel. 1997. Transaction costs and nonlinear adjustment in real exchange rates: an empirical investigation. Journal of Political Economy 105: 862-79.

Mishkin, F. S. 2004. The Economics of Money, Banking, and Financial Market (7 $7^{\text {th }}$ ed.). USA: The AddisonWesley series in economics.

Mobarek, A., and K. Keasey. 2002. Weak-form market efficiency of and emerging market: Evidence from Dhaka Stock Market of Bangladesh. E-document. Retrieved October 26, from: http:// www.bath.ac.uk/centers/CDS/Enbs-papers/Mobarek_new.htm.

Moustafa, M. A. 2004. Testing the weak-form efûciency of the United Arab Emirates Stock Market. International Journal of Business 9 (3).

Munir, Q., and K. Mansur. 2009. Is Malaysian Stock Market efficient? Evidence from threshold unit root tests. Economics Bulletin 29 (2): 1359-1370.

Narayan, P. K. 2005. Are the Australian and New Zealand stock prices nonlinear with a unit root? Applied Economics 37: 2161-2166.

Narayan, P. K. 2008. Do shocks to G7 stock prices have a permanent effect? Evidence from panel unit root tests with structural change. Mathematics and Computers in Simulation 77: 369-373.

Narayan, P. K., and R. Smyth. 2004. Is South Korea's stock market efficient? Applied Economics Letters 11: 707-710.

Narayan, P. K., and R. Smyth. 2005. Exchange rates and stock prices in South Asia: Evidence from Granger causality tests. ICFAI Journal of Applied Finance 11: 31-37.

Nelmida., N., M. Annuar, and T. Hassan. 2009. The impact of new information regime on the Jakarta Stock Exchange. International Research Journal of Finance and Economics (3). ISSN 1450-2887.

Ojah, K., and D. Karemera. 1999. Random walk and market efficiency tests of Latin American emerging equity markets: A revisit. The Financial Review (34) (2): 57-72.

Ozdemir, Z. A. 2008. Efficient market hypothesis: evidence from a small open-economy. Applied Economics 40: 633-641.

Perron, P. 1989. The great crash, the oil price shock and the unit root hypothesis. Econometrica 57: 1361401.

Peters, E. E. 1994. Fractal Market Analysis: Applying Chaos Theory to Investment and Economics. John Wiley and Sons.

Phillips, P. C.B., and P. Perron. 1988. Testing for a unit root in time series regression. Biometrika 75: 335346.

Poshakwale, S. 1996. Evidence on weak form efficiency and day of the week effect in the Indian Stock Market. Finance India X (3): 605-616. 
Poterba, J. M., and L. H. Summers. 1988. Mean reversion in stock prices: Evidence and implications. Journal of Financial Economics 22 (1): 27-59.

Qian, X. Y., F. T. Song, and W. X. Zhou. 2008. Nonlinear behaviour of the Chinese SSEC index with a unit root: Evidence from threshold unit root tests. Physica $A$ (387): 503-510.

Shively, P. A. 2003. The nonlinear dynamics of stock prices. The Quarterly Review of Economics and Finance 43: $505-517$.

Shleifer, A. 2000. Inefficient Markets. An Introduction to Behavioural Finance, Clarendon Lectures in Economics. Oxford: Oxford University Press.

TerSasvirta, T. 1994. Specifcation, estimation and evaluation of smooth transition autoregressive models. Journal of the American Statistical Association 89: 208-218.

Urrutia, J. L. 1995. Test of random walk and market efficiency for Latin American emerging equity markets. Journal of Financial Research 18: 299-309.

Zivot, E., and D.W. K. Andrews. 1992. Further evidence on the great crash, the oil-price shock and the unit root hypothesis. Journal of Business and Economic Statistics 10: 251-70.

Zulfadin, R. 2008. Random walk hypothesis test: An aplication of linear and non-linear test on Indonesia Stock Market indices. Jurnal Keuangan dan Moneter 11 (1). 